\title{
IMMIGRATION CONTROL \& LONG-RUN POPULATION WELFARE
}

\section{Gurgen Aslanyan}
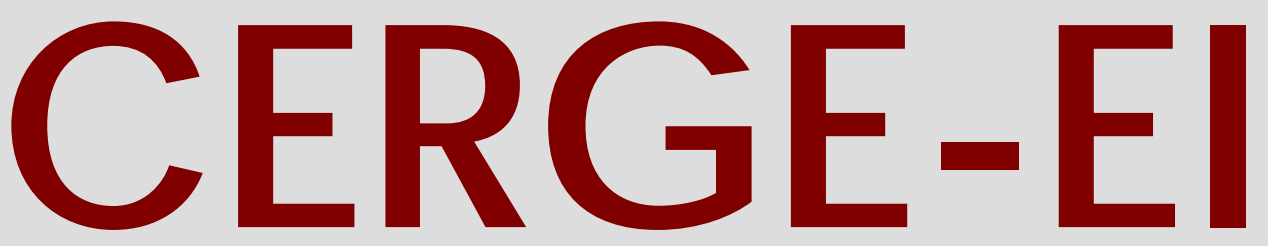

Charles University Centerfor Economic Research and Graduate Education Academy of Sciences of the Czech Republic Ec onomic s Institute 


\title{
Working Paper Series 453 (ISSN 1211-3298)
}

\section{Immigration Control \& Long-Run Population Welfare}

\author{
Gurgen Aslanyan
}

CERGE-EI

Prague, February 2012 
ISBN 978-80-7343-256-0 (Univerzita Karlova. Centrum pro ekonomický výzkum a doktorské studium)

ISBN 978-80-7344-248-4 (Národohospodářský ústav AV ČR, v.v.i.) 


\title{
Immigration Control E Long-Run Population Welfare

\author{
Gurgen Aslanyan*
} \\ CERGE-EI ${ }^{\ddagger}$
}

\begin{abstract}
The current study assesses the effects of immigration control on the welfare of the current and future population of a host economy. A theoretical model of a small open economy populated with overlapping generations of heterogeneous agents is used to show that skillfavouring immigration policies are, under rather permissive conditions, welfare depriving for the overall population. However, the policy-setting generation is shown to benefit from immigration control, thus decreasing the welfare for the future population.
\end{abstract}

\begin{abstract}
Abstrakt
Tato studie hodnotí efekty regulace imigrace na blahobyt současné a budoucí populace hostitelské země. Teoretický model malé otevřené ekonomiky obývané překrývajícími se generacemi heterogenních aktérů je použit k ukázání toho, jak regulace preferující dovednosti při imigraci, při některých poněkud benevolentních podmínkách, připravuje celkovou populaci o blahobyt. U generace, která regulaci nastavuje, je ale ukázáno, že na imigrační regulaci získává, čímž snižuje blahobyt budoucích generací.
\end{abstract}

Keywords: Immigration Control, Intergenerational Redistribution, Social Security

JEL classification: J18, F22, E24, H55, J15, E61

\footnotetext{
*Email: Gurgen. Aslanyan@cerge-ei.cz

${ }^{\dagger}$ I am particularly indebted to Byeongju Jeong for insightful discussions and continuous support. I benefited from the comments of Friedrich Breyer, Randall Filer, Selahattin Imrohoroglu, Gerard Roland, Jan Svejnar, and the discussants at the 2011 Warsaw International Economic Meeting, as well as the referee reports from Evangelia Vourvachaki and Sergey Slobodyan. I gratefully acknowledge the financial support from GDN Grant No. RRC IX-12. Any errors remaining in this text are the responsibility of the author.

${ }^{\ddagger}$ Center for Economic Research and Graduate Education--Economics Institute, a joint workplace of Charles University in Prague and the Academy of Sciences of the Czech Republic. Address: CERGE-EI, P.O. Box 882, Politických vězňo̊ 7, Prague 1, 111 21, Czech Republic
} 


\section{Introduction}

Many economies are designing (or redesigning) their national immigration policies as circumstances in the international labour markets rapidly change: Most of the developed world suffers from low fertility (that in tandem with increased longevity heavily burdens national budgets), while the labour markets in many developing economies are not able to absorb a continuously increasing population (making immigrant labour supply abundant). However, whereas most of the immigrant supply is unskilled, newly-designed immigration policies mostly favour skilled immigration, e.g. the European Blue Card Programme (Djajic, 2011).

The current paper examines preferential immigration policies, i.e. policies that favour a high share of skilled among immigrants. The effect of different immigration policies on the current and future population is studied, as immigration potentially may cause many unwanted changes in the economy, including intra- as well as inter-generational redistribution of welfare. While there is a vast literature on the impact of immigrants on the host economy (Borjas, 1994, 1999; Okkerse, 2008; and Akin, 2011, provide an excellent survey), the great majority of that work is concentrated on the instantaneous and short-term effects of those policies, ignoring the welfare of the future population.

Thus, Storesletten (2000), discussing the problem of the sustainability of the pension system with an ageing 'baby-boom generation', studies the impact of immigrants on the overall economy and advocates for a preferential immigration policy (further favouring advanced-age skilled immigrants). The results are driven by the fact that skilled immigrants with few remaining working years will contribute to the public budget the most while having the least probability for claiming benefits or 
fathering a 'costly' child. Lee $\&$ Miller (2000) in a similar model, but with a more developed demographic side (and less developed economic side), conclude that the preferential policies are better for social security when including the costs and benefits from the immigrants' direct descendants into the calculations. Storesletten (2003) confirmed the previous results in an open-economy environment (to simulate a typical European welfare state), vouching for preferential immigration.

In more recent work Chojnicki, Docquier 8 Ragot (2011), in line with the literature, claim that the welfare of the concerned generations would be higher should the United States have had a more selective immigration policy. Again, their study summarises the short-term effect on the population and does not look into future welfare. Lancomba $\mathscr{E}$ Lagos (2010) study the welfare effects of different generations in more detail in order to identify the political equilibrium in the host country and conclude that the population will vote for unskilled immigrants as almost every group is better off with this policy. However, Lancomba $\mathscr{E}$ Lagos do not consider voting for skilled vs unskilled immigration.

Razin \&f Sadka $(1999,2000)$ are pioneers in the literature that highlight the possible benefit of unskilled immigrants to the economy. They claim that, with an infinite horizon view, even unskilled immigrants Pareto improve the welfare of a heterogeneous population (while individually burdening the welfare state). In Razin $\&$ Sadka framework immigration can be understood as borrowing from the future through the pay-as-you-go (PAYG) pension system, and with the infinite horizon there is effectively no terminal point and thus none of the current or future generations will feel the burden of the migrants.

The current paper also discusses an infinite-horizon environment (as it is believed that an economy never ends). However, two different versions of the econ- 
omy are studied. In one case, the multiple-tax equilibrium, the economy runs a standard unfunded pay-as-you-go public pension system where the workers in each period contribute to the system so that the pensions are fully paid and the system is balanced each period (i.e. a standard defined benefit PAYG system popular in Europe). Thus each period the tax rate is set separately (hence the name 'multiple-tax' equilibrium).

In the second case, the single-tax equilibrium, a hypothetical case of one tax rate for the entire history of the economy is studied. The single-tax (or non-zero debt) equilibrium is an illuminating case as an 'average' effect of immigration policy. Incontestably, the single-tax equilibrium does not fit into the customary definition of the pay-as-you-go pension system (e.g., Uebelmesser, 2004). However, smoothing of fiscal spikes is a habitual practice worldwide (that has encouraged many researchers to consider 'single-tax' equilibrium to model social security budgets, e.g., Attanasio, Kitao $\mathscr{E}$ Violante, 2007; Nishiyama $\mathscr{E}$ Smetters, 2007). Moreover, following Breyer (1989) it is possible to show that the single-tax equilibrium corresponds to terminating the unfunded pension security system and using a single tax for financing the generated debt.

Though this paper does not explicitly consider political equilibrium, it is still assumed that voting favours a policy that enhances welfare for two cohabiting generations. Thus, in the case of single-tax equilibrium, the senescent population have no welfare changes and so if the young benefit from the preferential immigration policy then that policy will prevail (as there is no other generation participating in the hypothetical voting). As no intergenerational altruism is modelled, the effect of the immigrants on the particular period will be decisive.

Following Razin $\&$ Sadka (1999) and Storesletten (2003), a small-open-economy 
model with a population of overlapping generation of heterogeneous agents is constructed (to simulate a typical European economy). The model is abstracted from detailed labour and other price-setting markets (as the effects of immigration on those are still to be identified in the empirical literature) in order not to bias the results. ${ }^{1}$ Hence, in the current work the effect of immigration on the population welfare is channelled through public finances.

The demographic side of the model is amply developed: Aside from the usual characteristics (age, skill group), the generation of immigrant descendants is accounted for. Krieger (2004) illustrated that some slight changes in the assimilation of immigrant descendants may cause a reversal of theoretical results. Alas, current demographic research has yet to identify the true assimilation that immigrant descendants face. For instance, Storesletten (2000) and Razin \& Sadka (1999) assume that second-generation immigrants are identical to natives. Lee $\mathscr{G}$ Miller (2000) claim that second-generation immigrants still inherit half of their ancestors' characteristics (though the third generation is identical to the natives). In

\footnotetext{
${ }^{1}$ In theory, results depend whether capital, skilled labour, and unskilled labour are used as substitutes or complements in production as well as how unemployment is introduced in the country. Thus, Razin $\&$ Sadka (2000) repeated their experiment (Razin $\&$ Sadka, 1999) in a closed-economy framework, and reported some welfare redistribution in the host economy due to the distortions in the capital-labour ratio. Schou (2006) discusses a semi-open economy, where the labour market was only closed, and the immigrant and natives are perfect substitutes. Schou also reports unwanted welfare redistribution. Kemnitz (2003) works out the theoretical counterpart of Razin $\&$ Sadka (1999) with unemployment, and again claims some unwanted welfare redistribution in case immigrants disturb the native employment. Alas, the empirical literature is inconclusive on the particulars of the effect of unskilled immigration, and no firm consensus has yet been reached. Thus, Card (2005) argues that evidence for immigrants harming unskilled natives is scant. In a survey article Okkerse (2008) concludes that the literature has failed to establish a firm relationship between immigration and unemployment, and that new labourers can be absorbed into an economy without damaging the labour market position of residents. Furthermore, some recent empirical literature reveals positive indirect effects of immigration on the local population: Hence, Cortes (2008) shows the benefit of unskilled immigration through instantaneous effect on prices. Furtado 83 Hock (2010) highlighted the role of unskilled immigrants on the work-fertility tradeoffs for local skilled females.
} 
an empirical study Milewski (2010) identifies a set of variables that explains the assimilation to some extent. The current paper takes a safe stance on the issue and discusses two possible extremes of assimilation, full assimilation and no assimilation, and another illustrative intermediate, bearing in mind that neither of those plausibly describes the true assimilation path. ${ }^{2}$ Each case of assimilation is separately studied under each of the equilibria.

In the next section the model is presented. Section 3 discusses the results, and section 4 concludes.

\section{The Economic Environment}

A small-open-economy environment is used. The model implicitly assumes the existence of a firm that locally hires all the available labour. No financial institution is modelled: Savings and borrowings are made based on constant (world) prices. Explicitly the model is populated by heterogeneous agents and a government that manages the social security budget.

\subsection{Population}

The population differ in age (young, $i=0$, and senescent, $i=1$ ), in skill level (skilled, $s=1$, and unskilled, $s=0$ ) and number of previous generations in the economy. Immigrants, $m$, are introduced to the economy while young and are considered the first generation in the economy, $g=1$. Descendants of immigrant dynasties can be of any generation, $g=2,3, \ldots$, and the natives, $n$, belong to

\footnotetext{
${ }^{2}$ However, the true assimilation should be nested somewhere between the two extremes. The results are robust to both of the cases.
} 
dynasties $(g=\infty)$ present in the economy at time $t=0$.

While the share of skilled among immigrants, $\lambda \in(0,1)$, is a 'choice variable' for the government, the locals ( $l$, descendants of native and immigrant dynasties) are born skilled with some probability: The share of skilled among descendants of native dynasties is $\theta \in(0,1)$, and the share of skilled among immigrant dynasties is either $\lambda$ or $\theta$ depending on the assimilation process. ${ }^{3}$ (For notation also $\gamma(s, g)$ will be used as the probability for generation $g$ agent having skill level $s$.)

In the labour market the skill level directly translates into efficiency level, $\varepsilon(s)$. The skill level also co-determines, together with generational background, the fertility rate $\varphi(s, g)$ of the agents. Natives, for the sake of simplicity, are assumed to reproduce with unite fertility. ${ }^{4}$ Thus, if $\mu_{t}(i, s, g)$ is defined as a measure on type $(i, s, g)$ agents, the introduction of the new generation of (type s) natives can be presented as:

$$
\mu_{t+1}(0, s, 0)=\gamma(s, 0) \sum_{s^{\prime}} \mu_{t}\left(0, s^{\prime}, 0\right)
$$

and the introduction of the immigrant dynasty descendants as:

$$
\mu_{t+1}(0, s, g+1)=\gamma(s, g+1) \sum_{s^{\prime}} \mu_{t}\left(0, s^{\prime}, g\right) \cdot \varphi\left(s^{\prime}, g\right)
$$

\footnotetext{
${ }^{3}$ The immigrant dynasties will either assimilate fully and have the skill distribution of the natives, $\theta$, or fully inherit the ancestral skill distribution (with $\lambda$ as the share of skilled and $(1-\lambda)$ as the share of unskilled). The skill distribution is commonly believed (e.g. Card $\mathscr{E}$ Rothstein, 2007; Heath, Rothon $\mathscr{E}$ Kilpi, 2008) to be between the two, but for the sake of analytic simplicity only the extreme cases are considered.

${ }^{4}$ The constant population, though very optimistic for ageing societies, already makes unfunded pension systems costly for the participating population. Principally, welfare losses arise once the sum of the growth rates for the real wage and population is less than the real interest rate (Aaron, 1966).
} 
The size and quality of the first generation immigrants is a government policy:

$$
\mu_{t}(0, s, 1)=\gamma(s, 1) \cdot \psi \sum_{g \neq 1} \sum_{s^{\prime}} \mu_{t}\left(0, s^{\prime}, g\right)
$$

where $\psi$ is the size of the immigrant population compared to the local-born population. The government chooses not only the size of the group but also the share of skilled among the immigrants: $\lambda=\gamma(1,1)$.

Each agent stays in the model for two periods (except the initial senescent population, $\mu_{0}(1, s, n)$, that are present only for the second period of their lives), viz. individual ageing is deterministic:

$$
\mu_{t+1}(1, s, g)=\mu_{t}(0, s, g)
$$

i.e., everybody ages, stays in senescence for one period and leaves the model afterwards (also no return migration is allowed).

An individual agent maximises lifetime utility, which is derived from consumption in both periods:

$$
U\left(c_{t}^{t}, c_{t+1}^{t}\right)=v\left(c_{t}^{t}\right)+\beta v\left(c_{t+1}^{t}\right)
$$

where $c_{j}^{i}$ is the consumption of an agent born at time $i$ during time $j ; U(\cdot, \cdot)$ is a time-separable utility function with $\beta \in(0,1)$ being the time-discount coefficient and $v(\cdot)$ being a continuous, twice continuously differentiable, strictly increasing, 
strictly concave function that satisfies the Inada conditions. ${ }^{5}$ To finance consumption an agent uses labour income net of taxes and savings in the first period, and in the second period savings and social security benefits are used. Thus, at time $t$ a $(0, s, g)$ type agent faces the following budget constraints:

$$
\begin{aligned}
c_{t}^{t}+a_{t} & \leq w \varepsilon(s)\left(1-\tau_{t}\right) \\
c_{t+1}^{t} & \leq \rho w \varepsilon(s)+a_{t}(1+r)
\end{aligned}
$$

where $a_{t}$ is the savings, $\tau_{t}$ is the tax rate, and $\rho$ is the pension replacement rate $^{6}$. The agent's efficiency is $\varepsilon_{s}=\varepsilon(1)$ and $\varepsilon_{u}=\varepsilon(0)$.

\subsection{Government}

The government regulates immigration (as presented in eq. (3)) and implements the fiscal constitution: The fiscal constitution includes taxation, pension benefits and sustainability of public debt (if it exists), and can be presented as:

$$
\sum_{s, g} \rho w \varepsilon(s) \mu_{t}(1, s, g)+B_{t}(1+r)=\sum_{s, g} \tau_{t} w \varepsilon(s) \mu_{t}(0, s, g)+B_{t+1}
$$

and

$$
\lim _{t \longrightarrow \infty} B_{t} \cdot(1+r)^{-t}=0
$$

\footnotetext{
${ }^{5}$ Leisure is not considered in the utility function for notational simplicity: All of the following results hold with the conventional time-separable, CRRA utility function:

$$
U\left(c_{t}^{t}, c_{t+1}^{t}, n_{t}, n_{t+1}\right)=\sum \beta^{i} \frac{\left[\left(c_{t+i}^{t}\right)^{\alpha}\left(n_{t+i}\right)^{\gamma}\right]^{1-\delta}}{1-\delta}
$$

and the budget constraint (6)-(7): The agent's decision on leisure depends not on other (own or government) policy variables, only on parameters and interest rate.

${ }^{6}$ This specification follows Bismarckian social security system that allows intergenerational redistribution and excludes intragenerational redistribution.
} 
where $B_{t}$ is the debt at year $t$ (a borrowing from time $t-1$ due at time $t$ ). Equation (8) is a general dynamic budget constraint that allows for periodically balanced unfunded pay-as-you-go (PAYG, in case $B_{t}=0$ for any $t$ ) as well as dynamically balanced social security. If the dynamically balanced system is used (i.e. non-zero public debt is allowed, $B_{t} \neq 0$ for some $t$ ), then equation (8) needs to be augmented by the condition presented in (9) for sustainability.

\subsection{Equilibrium and Welfare Measure}

The economy starts with an established social security system and no immigration policy. Starting with the first period immigrants are invited in and the government manages the social security budget (taking into consideration the new demographic changes).

Definition 1. Given the (world) prices for labour and capital, $w$ and $r$, the replacement rate for public pension $\rho$, the rate of time preference $\beta$, skill and fertility rates $\varepsilon_{s}$ and $\varphi_{g, s}$, skill distribution $\gamma_{s, g}$, the initial value of public debt, $B_{0}$, and the size of the immigrant population compared to the native population $\psi$, the equilibrium in

the economy is an allocation $\left\{c_{0}^{1} ;\left\{c_{t}^{t}, c_{t+1}^{t}, a_{t}, \mu_{t}(i, s, g), \tau_{t}, B_{t}\right\}_{s=0,1 ; g=1,2 \ldots}^{i=0,1 ; t=1,2 \ldots}\right\}$, such that the initial (time $t=0$ ) senescent agents consume their savings and pension benefits, households optimise (5)-(7), the government budget (8)-(9) is balanced and sustainable, and the population evolves according to (1)-(4).

This definition allows infinitely many equilibria depending on the combination of tax rate and size of the public debt in each period. Thus, a further refinement (based on the variability of the tax rate) shall be used to restrict the equilibria to only two types: 
Definition 2. A single-tax (or non-zero debt) equilibrium is an equilibrium (as given in Definition 1) with a common tax rate set for all cohorts $t>0$

$$
\tau_{t}=\bar{\tau}
$$

while the public debt varies accordingly to satisfy (8)-(9).

Definition 3. A multiple-tax (or zero debt) equilibrium is an equilibrium (as given in Definition 1) where the tax rate is set so that the contributions are equal to the pension benefits in each period, and thus the government never borrows or saves, i.e. $B_{t}=0$ for any $t$.

In equilibrium the agents maximise their lifetime utility given the prices, tax rates, and pension replacement. Over the types of equilibria none of the mentioned varies but the tax rate. Thus ${ }^{7}$, the product of the pension replacement rate and the reciprocal of the tax rate shall be considered the measure of welfare:

$$
W_{t}=\frac{\rho}{\tau_{t}}
$$

Thence, while in the case of the multiple-tax equilibrium the welfare of (each agent in) the different cohorts will differ, in the case of the single-tax equilibrium one measure $W_{S T E}$ represents all the agents at once (with the exception of the initial (time $t=0$ ) senescent agents whose welfare is unaltered in any discussed equilibria).

\footnotetext{
${ }^{7}$ The first order conditions of the optimisation problem (5)-(7) give implicit functions of consumption in both life-periods depending inversely on $\tau_{t}: c_{t}^{t}=c_{t}^{t}\left(\tau_{t}\right)$ and $c_{t+1}^{t}=c_{t+1}^{t}\left(\tau_{t}\right)$.On the other hand $U\left(c_{t}^{t}, c_{t+1}^{t}\right)$ is strictly increasing in both arguments and thus is strictly decreasing in $\tau_{t}$.
} 


\subsection{Assimilation Dynamics}

In equilibrium the government sets a tax rate, based on the size of the effective labour force (the base for the contributions and the next period pension claims), to balance the budget (8)-(9). The size of the effective labour force depends on the absolute size of the population and their average efficiency:

$$
N_{t}=\sum_{s, g} \varepsilon(s) \mu_{t}(0, s, g)
$$

At the start of the economy half of the native population is young (age $i=0$ ), and the other half in senescence (age $i=1$ ). Thus the effective labour force at time $t=0$ is

$$
N_{o}=\mathcal{L}\left(\theta \varepsilon_{s}+(1-\theta) \varepsilon_{u}\right)=\mathcal{L} E_{\theta}
$$

where $\mathcal{L}$ is exactly half of the total population in the country, and $E_{\theta}$ is the average efficiency of a native worker. In period $t=1$ the government allows migrants to enter. Migrants immediately start participating in the local labour market and the social security system (by contributions first and then pension claims one period later). The government chooses the size of the immigrant group (relative to the local-born population, $\psi$ ) and the size of the skilled among migrants, $\lambda$, so that the average efficiency among immigrants is

$$
E_{\lambda}=\lambda \varepsilon_{s}+(1-\lambda) \varepsilon_{u}
$$

and the working age population at time $t=1$ is

$$
N_{1}=\mathcal{L}\left(E_{\theta}+\psi E_{\lambda}\right)
$$


From the second period on, the descendants of the immigrants enter the labour force and the effective labour force changes depending on their assimilation pattern. Thus the three cases are discussed.

\subsubsection{Full assimilation: Uninherited fertility and uninherited skills}

In the case of full assimilation, the second period starts with the natives creating young natives equal to themselves in number and average efficiency, while the immigrants father, with their respective fertility rates $\varphi_{s}=\varphi(s, 1)$, second generation immigrants that have the skill distribution of the natives. Next, the government allows a new cohort of young immigrants to enter the country according to (3), so that in the second period the efficient labour force is

$$
N_{2}=\mathcal{L}\left(E_{\theta}+\psi E_{\lambda}\right)\left(1+\psi \Phi_{\lambda}\right)
$$

where $\Phi_{\lambda}$ is the average fertility of the immigrants:

$$
\Phi_{\lambda}=\lambda \varphi_{1}+(1-\lambda) \varphi_{o}
$$

From the second period on the natives reproduce, the immigrant descendants behave identically to the natives, and the immigrants enter according to (3), so that the population at time $t \geqslant 2$ is

$$
N_{t}^{f a}=\mathcal{L}\left(E_{\theta}+\psi E_{\lambda}\right)\left(1+\psi \Phi_{\lambda}\right)^{t-1}
$$

i.e. increasing proportionally with the weighted sum of the local and immigrant fertility rates. 


\subsubsection{Partial assimilation: Inherited fertility and uninherited skills}

In the case of partial assimilation, the labour force dynamics are identical to the previous case up to the second period and can be presented by (13)-(16). However, from the beginning of the third period (while the natives reproduce, the immigrants father according to their fertility, $\Phi_{\lambda}$, and the government allows young immigrants to enter according to policy rule (3)) the second generation immigrants, having inherited the fertility level of their ancestors, produce third-generation immigrants with the skill-dependent fertility rate $\varphi_{s}$ (as the first-generation immigrants do).

The population at time $t \geqslant 2$ is

$$
N_{t}^{p a}=\mathcal{L}\left(E_{\theta}+\psi E_{\lambda}\right)\left(\frac{\psi \Phi_{\lambda}}{\Phi_{\theta}+\psi \Phi_{\lambda}-1}\left(\Phi_{\theta}+\psi \Phi_{\lambda}\right)^{t-1}+\frac{\Phi_{\theta}-1}{\Phi_{\theta}+\psi \Phi_{\lambda}-1}\right)
$$

where

$$
\Phi_{\theta}=\theta \varphi_{1}+(1-\theta) \varphi_{o}
$$

is the average fertility level of the immigrant descendants.

Hence, the immigrant generations differ in their average fertility both from the natives (unit fertility) and the immigrants (on average $\Phi_{\lambda}$ ). Furthermore, when the share of the skilled among the immigrant population is higher than the natives, the average fertility rate of the descendants is higher than that of the immigrants. Similar to the previous case of full assimilation, the labour force growth over time is driven by the weighted sum of the fertility rates, $\Phi_{\theta}+\psi \Phi_{\lambda}$; however, the labour force growth rate reaches that level only infinitely many periods later. 


\subsubsection{No assimilation: Inherited fertility and inherited skills}

In the extreme case of immigrant descendants being identical (in labour-market and reproductive qualities) to their ancestors, i.e. in the case of no assimilation, the size of the population is again the same as the previous two cases for the first two periods. However, while in the first period the labour force is again identical (and is given by (13)-(15)), the immigrant descendants are different in their skill distribution: The efficient labour force in the second period in case of no assimilation is:

$$
N_{2}^{n a}=\mathcal{L}\left(E_{\theta}+\psi E_{\lambda} \Phi_{\lambda}+\psi E_{\lambda}\left(1+\psi \Phi_{\lambda}\right)\right)
$$

which further changes both the population and the labour force size:

$$
N_{t}^{n a}=\mathcal{L}\left(E_{\theta}+\psi E_{\lambda} \frac{\Phi_{\lambda}^{t}(1+\psi)^{t}-1}{\Phi_{\lambda}(1+\psi)-1}\right)
$$

for $t \geqslant 1$. Again the weighted sum of the immigrant dynasty average fertility, $\Phi_{\lambda}(1+\psi)$, is the driving force for the labour force growth as well as is the limit value that the labour force (and population) growth rate approaches over time.

\section{Welfare Analysis}

Each case of the equilibria will be discussed separately: Single-tax equilibrium with full, partial or no assimilation, and multiple-tax equilibrium with full, partial or no assimilation. 


\subsection{Single-tax equilibrium}

The measure for welfare under the single-tax equilibrium is obtained from solving (8) and (9) for tax rate $\bar{\tau}$ and substituting in (11):

$$
W_{S T E}=(1+r)\left(1+\frac{N_{o}}{\sum_{t=1}^{\infty} \frac{N_{t}}{(1+r)^{t}}}\right)^{-1}
$$

It is apparent that welfare depends on the relation of the effective population and the real interest rate. Holding the working assumption that immigration never covers the gap between the internal and external returns of participating in an unfunded social security system (i.e., the population growth rate is lower than the real interest rate), it is possible to analyse the welfare measure under different cases of assimilation.

Lemma 1. In the single-tax equilibrium the welfare measure in the case of full, partial and no assimilation, respectively, reads:

$$
\begin{aligned}
W_{S T E}^{F A} & =\frac{E_{\theta}+E_{\lambda} \psi}{E_{\lambda} \psi+E_{\theta}(1+r)-\Phi_{\lambda} E_{\theta} \psi}(1+r) \\
W_{S T E}^{P A} & =\frac{E_{\theta}+E_{\lambda} \psi}{E_{\lambda} \psi+E_{\theta}(1+r)-\Phi_{\lambda} E_{\theta} \psi \frac{r}{\left(1+r-\Phi_{\theta}\right)}}(1+r) \\
W_{S T E}^{N A} & =\frac{E_{\lambda} \psi r}{E_{\lambda} \psi+E_{\theta}(1+r)-\Phi_{\lambda} E_{\theta}(1+\psi)}+1
\end{aligned}
$$

Proof. Follows directly from rearranging equations (13), (15), (16), (18), (19), (21)-(22), and (23). 
Proposition 1. In the single-tax equilibrium, welfare increases with the size of immigration (independent of the share of skilled among immigrants).

Proof. The derivatives of (24)-(26) are positive under the working assumption that the population growth rate is lower than the real interest rate.

Interpretation of Proposition 1 is based on the Breyer (1989) equivalence result. Thus, the single-tax equilibrium is equal to cancelling the existing pension system and turning the implicit pension debt (the due benefits) into an explicit public debt, and then distributing the debt equally over the future cohorts. Thus immigration (even unskilled) can be understood as an increase in the tax base (for financing a specific sum).

Proposition 2. In the single-tax equilibrium welfare, in the case of full assimilation, decreases with an increase in the share of skilled among immigrants if

$$
\frac{\varepsilon_{s}-\varepsilon_{u}}{\varphi_{u}-\varphi_{s}}<\frac{E_{\theta}+\psi E_{\lambda}}{r-\psi \Phi_{\lambda}}
$$

Proof. The derivative of (24) is

$$
\frac{\partial W_{S T E}^{F A}}{\partial \lambda}=P_{F A} \cdot\left(\frac{\partial E_{\lambda}}{\partial \lambda} r+\frac{\partial \Phi_{\lambda}}{\partial \lambda} E_{\theta}-\psi\left[\frac{\partial E_{\lambda}}{\partial \lambda} \Phi_{\lambda}-\frac{\partial \Phi_{\lambda}}{\partial \lambda} E_{\lambda}\right]\right)
$$

where $P_{F A}$ is a strictly positive function of model parameters, $\frac{\partial E_{\lambda}}{\partial \lambda}=\varepsilon_{s}-\varepsilon_{u}>0$ and $\frac{\partial \Phi_{\lambda}}{\partial \lambda}=\varphi_{s}-\varphi_{u}<0$. Hence, (28) is negative if $(27)$ holds. 
The proposition claims that under rather permissive assumptions ${ }^{8}$, namely, that the difference in efficiency rate is not disproportionately large compared to the difference in fertility rates, unskilled immigration is preferred. The intuition behind condition (27) is that if the losses (size of the pension system losses $\left(r-\psi \Phi_{\lambda}\right)$ multiplied by the losses in efficiency $\left.\left(\varepsilon_{s}-\varepsilon_{u}\right)\right)$ due to unskilled immigration are smaller than the gains (average efficiency $\left(E_{\theta}+\psi E_{\lambda}\right)$ multiplied by the gain in fertility $\left.\left(\varphi_{u}-\varphi_{s}\right)\right)$ due to unskilled immigration, then unskilled immigration is preferred.

Proposition 3. In the single-tax equilibrium welfare decreases with increase in the share of skilled among immigrants if

(a) in the case of partial assimilation

$$
\frac{\varepsilon_{s}-\varepsilon_{u}}{\varphi_{u}-\varphi_{s}}<\frac{E_{\theta}+\psi E_{\lambda}}{r-\psi \Phi_{\lambda}+1-\Phi_{\theta}}
$$

\footnotetext{
${ }^{8}$ Generally, the difference in efficiency and difference in fertility are rather similar, while $\left(r-\psi \Phi_{\lambda}\right)$ has a small positive value and $E_{\theta}>1$ by construction, so the inequality is virtually always satisfied.

For instance, Akin (2011) using German socio-economic panel data calibrated the fertility rates for the two immigrant skill groups, $\varphi_{s}=0.84$ and $\varphi_{u}=1.14$ (found in Akin, Table 6). Based on Akin, Table 4, assuming the unskilled as a numéraire, the efficiency levels can be computed, $\varepsilon_{s}=1.46$ and $\varepsilon_{u}=1$. Similarly, the share of skilled among natives can be computed from Akin, Table $7, \theta=0.31$.

To calculate the size of immigration, the current German annual level of 0.1 per cent of the entire population can be used for a 30-year period. Thus $\psi=(1+0.002)^{30}-1=0.06$. For obtaining the real interest rate, Eurostat data on annual government bond yields on ten-year maturities over five pre-crisis years (2003-2007) is used to calculate the average 3.848 per cent. As the model does not account for economic growth, the average growth rate of Germany over the same years, 2.978, is subtracted and the remaining 0.87 per cent is used as a base for compound interest calculation $r=(1+0.0087)^{30}=0.297$. Thus, using these data the inequality (27) can be re-written

$$
\frac{0.46}{0.3}<\frac{1.2+0.03 \lambda}{0.23+0.02 \lambda}
$$

As $\lambda \in(0,1)$, the right-hand side of the above inequality falls into the interval $(4.92,5.22)$. Hence the inequality holds for any $\lambda$.
} 
(b) in the case of no assimilation

$$
\frac{\varepsilon_{s}-\varepsilon_{u}}{\varphi_{u}-\varphi_{s}}<\frac{1+\psi}{1+r-\Phi_{\lambda}(1+\psi)}
$$

Proof. The derivatives of (25) and (26):

$$
\begin{aligned}
& \frac{\partial W_{S T E}^{P A}}{\partial \lambda}=P_{P A} \cdot\left[\frac{\partial E_{\lambda}}{\partial \lambda}\left(1+r-\left(\Phi_{\theta}+\psi \Phi_{\lambda}\right)\right)+\frac{\partial \Phi_{\lambda}}{\partial \lambda}\left(E_{\theta}+\psi E_{\lambda}\right)\right] \\
& \frac{\partial W_{S T E}^{N A}}{\partial \lambda}=P_{N A} \cdot\left[\frac{\partial E_{\lambda}}{\partial \lambda}\left(1+r-\Phi_{\lambda}(1+\psi)\right)+\frac{\partial \Phi_{\lambda}}{\partial \lambda}(1+\psi)\right]
\end{aligned}
$$

(where $P_{P A}$ and $P_{N A}$ are positive) are negative if, respectively, (29) and (30) hold.

Again under rather permissive assumptions, unskilled immigration is preferred. The economic intuition is also similar to the previous case.

\subsection{Multiple-tax equilibrium}

In the multiple-tax equilibrium the welfare measure collapses to simple efficient population change, and the welfare dynamics are effectively the population dynamics:

$$
W_{t}=\frac{N_{t}}{N_{t-1}}
$$

Lemma 2. The young of the first period (irrespective of the assimilation scenario) have the welfare:

$$
W_{1}^{F A}=W_{1}^{P A}=W_{1}^{N A}=\frac{E_{\theta}+E_{\lambda} \psi}{E_{\theta}}=1+\frac{E_{\lambda}}{E_{\theta}} \psi
$$


Proof. Follows directly from (13), (15), and (33).

Proposition 4. In the multiple-tax equilibrium, the welfare of the first-period young (i.e. the policy-setting cohort) increases with the share of the skilled among immigrants.

Proof. The derivative of the right-hand side of (34) with respect to the share of skilled among immigrants, $\lambda$, is $\frac{\psi}{E_{\theta}}\left(\varepsilon_{s}-\varepsilon_{u}\right)>0$.

Palpably, the voting equilibrium without dynastic altruism will result in a selective immigration policy where only skilled immigrants are allowed in: The welfare of the senescent group is unaltered while the young are strictly better off.

Lemma 3. If the immigrant descendants fully assimilate, the welfare at period $t \geqslant 2$ is:

$$
W_{t \geqslant 2}^{F A}=1+\psi \Phi_{\lambda}
$$

Proof. Follows directly from (15), (18), and (33).

Proposition 5. If the immigrant descendants fully assimilate, the welfare of $t \geqslant 2$ (i.e. everyone, but the policy-setting cohort) decreases with an increase in the share of the skilled among immigrants.

Proof. The derivative of (35) with respect to the share of skilled among immigrants $\lambda$ is $\psi\left(\varphi_{s}-\varphi_{u}\right)<0$.

Propositions 4 and 5 suggest that there is a strong conflict of interest between the first and subsequent cohorts of the population: While the first cohort strictly prefers skilled immigrants, all the other cohorts enjoy higher welfare if the policy does not favour the skilled. The lower the share of skilled among immigrants the 
higher the welfare of the later cohorts is. However, it is worth noting that, if the share of skilled among immigrants is very small, the initial cohort may have lower welfare than their descendants.

Proposition 6. In the case of full assimilation, if

$$
E_{\lambda}<E_{\theta} \Phi_{\lambda}
$$

then the welfare of the first (policy-setting) cohort is lower than the welfare of all the other cohorts.

Proof. Follows directly from (34) and (35).

That is, if the efficient size of the immigrant population is less than the efficient size of the immigrant descendant population (average efficiency multiplied by size) then the first cohort is worse off compared to every other cohort. The reverse also holds, i.e. if the share of skilled among immigrants is high, then the first generation measure of welfare is higher than that of the other cohorts. ${ }^{9}$

Lemma 4. If the immigrant descendants partially assimilate, the welfare of the agents in the second period is

$$
W_{2}^{P A}=1+\psi \Phi_{\lambda}
$$

${ }^{9}$ The inequality (36) can be rewritten in simpler form to express in terms of the share of skilled among immigrants

$$
\lambda<\frac{E_{\theta} \varphi_{u}-\varepsilon_{u}}{E_{\theta}\left(\varphi_{u}-\varphi_{s}\right)+\varepsilon_{s}-\varepsilon_{u}}
$$

Using the numbers from previous calculations (footnote 8 ), $E_{\theta}=1+0.31 \cdot 0.46=1.1426$, the nominator becomes $1.14 \cdot 1.1426-1=0.3025$, the denominator is $0.46+1.1426 \cdot 0.3=0.8028$. Hence, when $\lambda<0.3025 / 0.8028=0.377$ the first (policy-setting) cohort has lower welfare than all the others. It is worth noting that the calculated value for share of skilled among immigrants that makes the first cohort better off, $\lambda>0.377$, is well above the calculated share of skilled among natives $\theta=0.31$. 
then grows over time according to

$$
W_{t>2}^{P A}=\frac{\Phi_{\theta}-1+\psi \Phi_{\lambda}\left(\Phi_{\theta}+\psi \Phi_{\lambda}\right)^{t}}{\Phi_{\theta}-1+\psi \Phi_{\lambda}\left(\Phi_{\theta}+\psi \Phi_{\lambda}\right)^{t-1}}
$$

and approaches level of

$$
W_{\infty}^{P A}=\Phi_{\theta}+\psi \Phi_{\lambda}
$$

in the limit.

Proof. (37) and (38) follow directly from (15), (19), and (33). The derivative of (38) with respect to time $t$ :

$$
\frac{\partial}{\partial t} W_{t>2}^{P A}=\frac{\Phi_{\lambda} \psi\left(\Phi_{\theta}-1\right)\left(\Phi_{\lambda} \psi+\Phi_{\theta}-1\right)\left(\Phi_{\lambda} \psi+\Phi_{\theta}\right)^{t+1}}{\left(\left(\Phi_{\lambda} \psi+\Phi_{\theta}\right)\left(\Phi_{\theta}-1\right)+\Phi_{\lambda} \psi\left(\Phi_{\lambda} \psi+\Phi_{\theta}\right)^{t}\right)^{2}} \ln \left(\Phi_{\lambda} \psi+\Phi_{\theta}\right)
$$

is positive given that $\Phi_{\theta}>1$ by construction. Also, it is straightforward to note that

$$
\lim _{t \rightarrow \infty} \frac{\Phi_{\theta}-1+\psi \Phi_{\lambda}\left(\Phi_{\theta}+\psi \Phi_{\lambda}\right)^{t}}{\Phi_{\theta}-1+\psi \Phi_{\lambda}\left(\Phi_{\theta}+\psi \Phi_{\lambda}\right)^{t-1}}=\Phi_{\theta}+\psi \Phi_{\lambda}
$$

thus proving the last part of the lemma.

Proposition 7. If the immigrants descendants partially assimilate, the welfare of $t \geqslant 2$ (i.e. everyone, but the policy-setting cohort) decreases with an increase in the share of the skilled among immigrants.

Proof. The derivative of (38) with respect to the share of skilled among immigrants $\lambda$ is $P_{t}^{P A} \cdot\left(\varphi_{s}-\varphi_{u}\right)<0$ where $P_{t}^{P A}>0$.

As in the case of full assimilation, the results unequivocally indicate the reverse effect of skilled immigration on the welfare of the first (policy-setting) cohort and 
all the subsequent cohorts: While the first cohort is better off with skilled immigrants, future cohorts prefer the unskilled. However, as opposed to the case of full assimilation, in the case of partial assimilation there is a possibility that the first cohort will have higher welfare than the cohorts immediately following after, but in future there will be cohorts that will enjoy welfare higher than that of the first generation.

Proposition 8. In the case of partial assimilation

(a) the first cohort has lower welfare compared to all the other cohorts, if

$$
E_{\lambda}<E_{\theta} \Phi_{\lambda}
$$

(b) the first cohort has higher welfare compared to all the other cohorts, if

$$
E_{\lambda}>E_{\theta}\left(\Phi_{\lambda}+\frac{\Phi_{\theta}-1}{\psi}\right)
$$

(c) the first cohort has higher welfare compared to some immediately following cohorts $t \in(2, \bar{t})$, but lower than the welfare of the cohorts $t>\bar{t}$, if

$$
E_{\theta} \Phi_{\lambda}<E_{\lambda}<E_{\theta}\left(\Phi_{\lambda}+\frac{\Phi_{\theta}-1}{\psi}\right)
$$

Proof. Appropriate comparison of (34), (37) and (39) with slight reshuffling result in (42)-(44).

Thus, the dynamics in the case of partial assimilation are richer, allowing different welfare ranking, but again a large share of skilled immigrants allows the first 
cohort to have the highest welfare (and the higher the share the higher the welfare is), while a small number of skilled among immigrants gives the first cohort the lowest welfare.

Lemma 5. If the immigrant descendants do not assimilate, the welfare of cohorts $t \geqslant 2$ is

$$
W_{t \geqslant 2}^{N A}=\frac{\left(\Phi_{\lambda}(1+\psi)-1\right) E_{\theta}+\left(\Phi_{\lambda}^{t+1}(1+\psi)^{t+1}-1\right) E_{\lambda} \psi}{\left(\Phi_{\lambda}(1+\psi)-1\right) E_{\theta}+\left(\Phi_{\lambda}^{t}(1+\psi)^{t}-1\right) E_{\lambda} \psi}
$$

that reaches the limit value of $W_{\infty}^{N A}=\Phi_{\lambda}(1+\psi)$, while growing if

$$
\Phi_{\lambda}(1+\psi)>1+\frac{E_{\lambda}}{E_{\theta}} \psi
$$

and decreasing otherwise.

Proof. From (22) and (33) directly follows (45). The limit value of (45) is also easily obtainable. The derivative of (45) with respect to time is

$$
\frac{\partial}{\partial t} W_{t \geqslant 2}^{N A}=\frac{F_{\lambda, \psi} E_{\lambda} \psi\left(F_{\lambda, \psi}+1\right)^{t} \ln \left(F_{\lambda, \psi}+1\right)}{\left(F_{\lambda, \psi} E_{\theta}+\left(\left(F_{\lambda, \psi}+1\right)^{t}-1\right) E_{\lambda} \psi\right)^{2}}\left(F_{\lambda, \psi} E_{\theta}-E_{\lambda} \psi\right)
$$

where

$$
F_{\lambda, \psi}=\Phi_{\lambda}(1+\psi)-1
$$

Expression in (47) is positive if the second multiplier in the product is positive. The (46) presents the required condition.

Proposition 9. In the case of no assimilation, if condition (46) holds, i.e.

$$
\lambda<\frac{E_{\theta} \varphi_{u}-\varepsilon_{u}}{E_{\theta}\left(\varphi_{u}-\varphi_{s}\right)+\varepsilon_{s}-\varepsilon_{u}}
$$


then the first cohort (i.e. the policy-setting cohort) has the lowest welfare that sequentially increases for subsequent cohorts.

If condition (46), or (49), holds with the opposite sign, the first cohort has the highest welfare, while welfare sequentially decreases for the subsequent cohorts.

If the expressions on both sides of (46), or (49), are equal, then the welfare measure for all cohorts $t \geqslant 1$ are the same.

Proof. The welfare of the socond cohort is

$$
\begin{aligned}
W_{2}^{N A} & =\frac{\left(\Phi_{\lambda}(1+\psi)-1\right) E_{\theta}+\left(\Phi_{\lambda}^{3}(1+\psi)^{3}-1\right) E_{\lambda} \psi}{\left(\Phi_{\lambda}(1+\psi)-1\right) E_{\theta}+\left(\Phi_{\lambda}^{2}(1+\psi)^{2}-1\right) E_{\lambda} \psi} \\
& =1+\frac{\Phi_{\lambda}^{2}(1+\psi)^{2} E_{\lambda} \psi}{E_{\theta}+\left(\Phi_{\lambda}(1+\psi)+1\right) E_{\lambda} \psi}
\end{aligned}
$$

which is more than the welfare of the first cohort $\left(W_{2}^{N A}>W_{1}^{N A}\right)$ if

$$
1+\frac{\Phi_{\lambda}^{2}(1+\psi)^{2} E_{\lambda} \psi}{E_{\theta}+\left(\Phi_{\lambda}(1+\psi)+1\right) E_{\lambda} \psi}>1+\frac{E_{\lambda}}{E_{\theta}} \psi
$$

The expression simplifies into (46), or further into (49). Under the same condition (46), according to Lemma 5, the welfare measure for all subsequent cohorts grows. This concludes the proof for the first part of the proposition. The other two cases are proved similarly.

Again it is clear that the first cohort benefits from a high-skilled-favouring immigration policy, and that later cohorts would prefer the share of skilled immigrants to be smaller initially. A highly-skilled immigrant group leaves the first (policy-setting) cohort with high welfare, while the welfare of all subsequent cohorts decreases rapidly. 
Of note is that the model is dynamically inconsistent and any cohort will prefer to increase the share of skilled among immigrants in their own period, thus increasing its own and decreasing the subsequent cohorts' welfare.

\section{Conclusion}

International labour mobility is reaching new heights in recent years. Additionally, over the last decades the pattern of immigration has reversed: Many traditionally source economies are now recipients. Thus, a majority of these economies (European Union countries in particular) are currently redesigning their immigration policies. The destination countries seem inclined to to follow the established policies of more experienced host countries, such as the United Kingdom or Australia, where a so-called point system is employed. The point system is a mechanism of screening the skills of immigrants and allowing entry only to the skilled (vis-à-vis the unskilled). An illustrative example is the Blue Card currently in design in the EU.

The current paper studies the effect of the skilled immigration on the welfare of the host country. A small open economy is considered with overlapping generations of heterogeneous agents. The agents differ in various characteristics, such as age, skill level, and the generation in the economy. The agents are also modelled to be different in their fertility levels. A minimalistic approach is taken for modelling purposes (to eschew possible theoretical uncertainties and biases).

Two types of equilibria are studied: a single-tax equilibrium, which illustrates the average effect of the policy over the entire future population as well as the case of privatising the unfunded social security system at the expense of public debt to 
be paid by current and future populations alike; and a multiple-tax equilibrium, in which each cohort of the population faces a different tax that balances the government budget and results in different welfare levels. For each equilibrium three different cases are discussed depending on the assimilation of the descendants of the immigrant population: Among the infinitely many possibilities of assimilation, two extremes are studied (full assimilation and no assimilation) and an illustrative intermediate case of partial assimilation, when over generations the immigrant descendants inherit the fertility level of their ancestors but adopt the skill level of the native population. All other cases are assumed to be between the extremes.

The results show that a skill-favouring immigration policy most often decreases welfare in the economy in the single-tax equilibrium. That is, the overall effect of the point-system immigration is negative for the host economy under the condition that the efficiency gain is not disproportionately large compared to the fertility losses when choosing skilled immigrants. It is shown that when the model is calibrated to fit an actual economy, the required condition is satisfied for any skill level.

Moreover, in the multiple-tax equilibrium it is apparent that the first cohort, i.e. the policy designers, benefit from a policy of skilled immigration, while all the others are worse off when compared to a immigration policy that allows more unskilled immigrants into the economy. Hence in a hypothetical political equilibrium, where only the (non-altruistic) first cohort votes, a skill-favouring immigration policy will be chosen.

The results thus suggest that the decision-making policy-setting initial generation has an incentive to choose an average-welfare-depriving policy of favouring the skilled. However, the model does not suggest any optimal policy to follow: De- 
creasing the share of skilled immigrants increases the welfare of the average agent, yet decreases the welfare of the decision makers up to the point that the policysetting first cohort may have the lowest welfare of all. Moreover, each subsequent cohort has an incentive to increase the share of skilled among immigrants in their own period (if policy alterations were allowed). Hence the conclusion is that, on the one hand, while point-system skill-favouring immigration policies are welfare decreasing for the overall economy, on the other hand, unskilled immigration is a dynamically inconsistent policy. 


\section{References}

Aaron, H. (1966). The social insurance paradox. The Canadian Journal of Economics and Political Science, 32, 371-374.

Akin, S.N. (2011). Immigration, fiscal policy, and welfare in an aging population. B.E. Journal of Macroeconomics, R\&R.

Attanasio, O., Kitao, S., \& Violante, G.L. (2007). Global demographic trends and social security reform. Journal of Monetary Economics, 54, 144-198.

Borjas, G.J. (1999). The economic analysis of immigration. In O. Ashenfelter and D. Card (Eds.). Handbook of Labor Economics, Volume 3A, 1698-1760.

Borjas, G.J. (1994). The economics of immigration. Journal of Economic Literature, 32, 1667-1717.

Breyer, F. (1989). On the intergenerational Pareto efficiency of pay-as-you-go financed pension systems. Journal of Institutional and Theoretical Economics, 145, 643-658.

Card, D. (2005). Is the new immigration really so bad? The Economic Journal, F300-F323.

Card, D., \& Rothstein, J. (2007). Racial segregation and the black-white test score gap. Journal of Public Economics, 91, 2158-2184.

Cortes, P. (2008). The effect of low-skilled immigration on US prices: Evidence from CPI data. Journal of Political Economy, 116, 381-422.

Chojnicki, X., Docquier, F., \& Ragot, L. (2011). Should the US have locked heaven's door? Reassesing the benefits of postwar immigration. Journal of Population Economics, 24, 317-359. 
Djajic, S. (2011). Reforming the system of international migration. In M.N. Jovanovic (Ed.) International Handbook on the Economics of Integration, Volume III: Factor Mobility, Agriculture, Environment and Quantitative Studies. 169-183. Edward Elgar Publishing.

Furtado, D., \& Hock, H. (2010). Low skilled immigration and work-fertility tradeoffs among high skilled US natives. American Economic Review: Papers and Proceedings, 100, 224-228.

Heath, A.F., Rothon, C., \& Kilpi, E. (2008). The second generation in Western Europe: Education, unemployment, and occupational attainment. Annual Review of Sociology, 34, 211-235.

Krieger, T. (2004). Fertility rates and skill distribution in Razin and Sadka's migration-pension model: A note. Journal of Population Economics, 17, 177182.

Lacomba, J.A., \& Lagos, F. (2010). Immigration and pension benefits in the host country. Economica, 77, 283-295.

Lee, R., \& Miller, T. (2000). Immigration, social security, and broader fiscal impacts. The American Economic Review, 90(2), 350-354.

Milewski, N. (2010). Fertility of immigrants. Demographic Research Monographs. Berlin: Springer-Verlag.

Nishiyama, S., \& Smetters, K. (2007). Does social security privatization produce efficiency gains. The Quarterly Journal of Economics, 122, 1677-1719.

Okkerse, L. (2008). How to measure labour market effects of immigration: A review. Journal of Economic Surveys, 22, 1-30. 
Razin, A., \& Sadka, E. (2000). Unskilled migration: A burden or a boon for the welfare state. Scandinavian Journal of Economics, 102, 463-479.

Razin, A., \& Sadka, E. (1999). Migration and pension with international capital mobility. Journal of Public Economics, 74, 141-150.

Storesletten, K. (2003). Fiscal implications of immigration: A net present value calculation. Scandinavian Journal of Economics, 105, 487-506.

Storesletten, K. (2000). Sustaining fiscal policy through immigration. Journal of Political Economy, 108, 300-323.

Uebelmesser, S. (2004). Unfunded Pension System: Ageing and Migration. Amsterdam: Elsevier. 


\section{Working Paper Series}

ISSN 1211-3298

Registration No. (Ministry of Culture): E 19443

Individual researchers, as well as the on-line and printed versions of the CERGE-EI Working Papers (including their dissemination) were supported from the following institutional grants:

- Economic Aspects of EU and EMU Entry [Ekonomické aspekty vstupu do Evropské unie a Evropské měnové unie], No. AVOZ70850503, (2005-2011);

- Economic Impact of European Integration on the Czech Republic [Ekonomické dopady evropské integrace na ČR], No. MSM0021620846, (2005-2011);

Specific research support and/or other grants the researchers/publications benefited from are acknowledged at the beginning of the Paper.

\section{(c) Gurgen Aslanyan, 2012}

All rights reserved. No part of this publication may be reproduced, stored in a retrieval system or transmitted in any form or by any means, electronic, mechanical or photocopying, recording, or otherwise without the prior permission of the publisher.

Published by

Charles University in Prague, Center for Economic Research and Graduate Education (CERGE) and

Economics Institute ASCR, v. v. i. (EI)

CERGE-El, Politických vězňů 7, 11121 Prague 1, tel.: +420 224005 153, Czech Republic.

Printed by CERGE-EI, Prague

Subscription: CERGE-EI homepage: http://www.cerge-ei.cz

Phone: + 420224005153

Email: office@cerge-ei.cz

Web: http://www.cerge-ei.cz

Editor: Michal Kejak

Editorial board: Jan Kmenta, Randall Filer, Petr Zemčík

The paper is available online at http://www.cerge-ei.cz/publications/working_papers/.

ISBN 978-80-7343-256-0 (Univerzita Karlova. Centrum pro ekonomický výzkum a doktorské studium)

ISBN 978-80-7344-248-4 (Národohospodářský ústav AV ČR, v. v. i.) 
CERGE-EI

P.O.BOX 882

Politických vězňů 7

11121 Praha 1

Czech Republic http://www.cerge-ei.cz 